\title{
FINANCIAL LIBERALIZATION IN A SMALL OPEN ECONOMY
}

\author{
JUERGEN VON HAGEN \\ HAIPING ZHANG
}

\author{
CESIFO WORKING PAPER NO. 1771 \\ CATEgory 6: MONETARy Policy and INTERnATIONAL FINANCE \\ AUgust 2006
}

Presented at CESifo Area Conference on Global Economy, April 2006

An electronic version of the paper may be downloaded

- from the SSRN website:

- from the RePEc website:

www.SSRN.com

- from the CESifo website:

www.RePEc.org

www.CESifo-group.de 


\title{
FINANCIAL LIBERALIZATION IN A SMALL OPEN ECONOMY
}

\begin{abstract}
We analyze the long-run and short-run implications of financial liberalization in a small open economy. Our main results are as follows. First, whether financial deregulation in one sector can improve production efficiency may depend on financial regulation in other sectors. Second, financial liberalization may have opposite welfare implications to domestic agents with different productivity in the long run. Third, although some domestic agents lose in the long run, they benefit from financial liberalization during the transitional process of deregulation. Finally, a gradual implementation helps achieve a smooth transition.
\end{abstract}

JEL Code: E32, E44, F34, F41.

Keywords: financial frictions, financial liberalization, foreign borrowing, macroeconomic fluctuations, overshooting.

\author{
Juergen von Hagen \\ University of Bonn \\ Lennéstr. 37 \\ 53113 Bonn \\ Germany \\ vonhagen@uni-bonn.de
}

\author{
Haiping Zhang \\ University of Bonn \\ Lennéstr. 37 \\ 53113 Bonn \\ Germany \\ hzhang@uni-bonn.de
}

April 2006

We thank Klaus Wälde, Christopher J. Waller, John Whalley, Gerald Willmann and the seminar participants at Indiana University and CESifo for helpful comments. 


\section{Introduction}

According to neoclassical models, financial liberalization has significant economic benefits. International capital flows provide developing economies with the means to exploit promising investment opportunities; at the same time, international investors are able to earn higher returns and to reduce risk via international portfolio diversification (Stulz, 2005). Caballero and Krishnamurthy $(2001,2003)$ investigate the dynamic interactions between domestic and international collateral constraints and show that limited financial development reduces the incentives for foreign lenders to enter emerging markets. Iacoviello and Minetti (forthcoming) assume that foreign lenders differ from domestic lenders in their ability to recover value from borrowers' assets and, therefore, to protect themselves against contractual non-enforceability. They show that such a model helps explain the comovement of output across countries. Aoki, Benigno, and Kiyotaki (2005) analyze the medium-run adjustment process after capital account liberalization and show that production efficiency depends on the degree of capital account liberalization. Alessandria and Qian (2005) examine the impact of foreign borrowing on both welfare and the structure of lending contracts. The entry of foreign investors to the domestic financial market may improve or worsen the efficiency of financial intermediaries, leading to an improvement or worsening of the aggregate composition of investment projects.

During the past two decades, many countries have deregulated financial markets and reduced explicit barriers to foreign investors. As a result, global capital flows have achieved record highs relative to global income. However, financial liberalization might have unequal welfare implications to different domestic agents. Furthermore, the policy sequencing and implementation strategy are of great importance for the success of financial liberalization. Recent experience with financial crises clearly suggests that mistakes in the policy implementation can contribute to severe macroeconomic consequences, e.g., sudden stops (WorldBank, 2005).

We address three related questions concerning financial liberalization in a small open economy, given that the foreign interest rate is smaller than the domestic interest rate. Does financial liberalization and the resulting capital inflow improve production efficiency in the domestic economy? Who benefits from financial liberalization in the long run and in the short run? Should financial liberalization be implemented gradually or hastily?

As financial liberalization is a multi-dimensional issue, its various components may have sophisticated interactions, which complicate the policy evaluation. Our main results are as follows. First, whether financial deregulation in one sector can improve production 
efficiency may depend on financial regulation in other sectors. Second, financial liberalization may have opposite welfare implications to domestic agents with different productivity in the long run. It helps explain the fact that financial liberalization receives support and opposition from different domestic interest groups. Third, although some domestic agents lose in the long run, they actually benefit from financial liberalization in the short run, i.e., during the transitional process of deregulation. Finally, a gradual implementation helps achieve a smooth transition of financial liberalization.

Our results can be shown intuitively as follows. In a small open economy with the infinite time horizon, there are two types of domestic private agents: households and entrepreneurs. They have production projects using a durable physical asset, e.g., land, as input. The project that entrepreneurs choose in equilibrium is expected to be more productive than the household project. As households are risk averse and the entrepreneurs' projects are subject to idiosyncratic risk, mutual funds emerge as financial intermediaries. They collect deposits from households and lend to entrepreneurs. If entrepreneurs could credibly pledge all of their project outcomes for external funds, land would be all allocated to entrepreneurs. However, due to financial frictions, land is not fully allocated to entrepreneurs and some of the land stock is inefficiently allocated to households. Given that land has a fixed total supply, production efficiency in the domestic economy can be measured by the fraction of the entrepreneurs' land holding in the total land stock. There are two types of domestic assets: a physical asset (land) and a financial asset (household deposit at the mutual funds).

A continuum of foreign lenders who are risk neutral supply funds at a constant interest rate lower than the domestic interest rate. Due to limited enforcement problem, domestic agents have to pledge their domestic assets for foreign funds. We assume, for simplicity, that a domestic public financial regulator has full power in determining the fraction of domestic assets pledgable for foreign funds. Financial liberalization is modeled as the process during which the public financial regulator raises such fractions and thus, domestic agents can borrow more abroad.

Our first result says that whether deregulating land-backed foreign borrowing can improve production efficiency depends on financial regulation on deposit-back foreign borrowing. Our second result says that due to the substitution of cheap foreign loans for domestic loans, the domestic agents with low productivity (households) lose strictly while the domestic agents with high productivity (entrepreneurs) may benefit from financial liberalization in the long run. Consider first the case of deregulating deposit-backed foreign borrowing, keeping the regulation on land-backed foreign borrowing constant. Households 
are allowed to borrow abroad against a larger fraction of their deposits. According to the no-arbitrage condition, the interest rate differential between domestic and foreign loans becomes smaller. Although entrepreneurs cannot increase their land-backed foreign borrowing much, they can acquire cheaper domestic loans and more land is allocated into their projects in the long run. As the wealth and the welfare of entrepreneurs are proportional to their land holding, they benefit strictly. Deregulating deposit-backed foreign borrowing leads to the substitution of cheap foreign funds for household net deposits. In addition, the unfavorable land reallocation and the resulting decline in their sales revenues have the negative effect on household wealth. Households have to reduce consumption and increase labor supply, i.e., households lose strictly in the long run. Therefore, deregulating deposit-backed foreign borrowing improves production efficiency and has opposite longrun welfare implications to households and entrepreneurs. These results do not depend on the regulation on land-backed foreign borrowing.

Things become complicated in the case of deregulating land-backed foreign borrowing. If deposit-backed foreign borrowing is highly regulated, there is a large interest rate differential between domestic loans and foreign loans. Deregulating land-backed foreign borrowing allows domestic agents to acquire more foreign funds against their land holding. Although households can also borrow more abroad, the average cost of external funds of entrepreneurs declines more than that of households and thus, more land is allocated to the entrepreneurs' projects. In this case, deregulating land-backed foreign borrowing has similar efficiency and welfare implications as in the case of deregulating deposit-backed foreign borrowing mentioned above.

If deposit-backed foreign borrowing is already highly deregulated, the domestic interest rate is very close to the foreign rate. Deregulating land-backed foreign borrowing does not reduce the average cost of entrepreneurs' external funds very much, while the cost of households' external funds declines significantly. As a result, more land is allocated into the household projects and production becomes less efficient. Due to the substitution of foreign loans for domestic loans, household net deposits decline and so do their wealth and welfare. At the same time, the decline in the entrepreneurs' land stock corresponds to the decline in their net wealth and their welfare. Thus, deregulating land-backed foreign borrowing may not necessarily improve production efficiency and may have negative longrun welfare implications to both households and entrepreneurs. Such results depend on the regulation on deposit-backed foreign borrowing.

Our third result says that although households lose strictly in the long run, they indeed benefit in the short run. Intuitively, as some of household net deposits are even- 
tually crowded out by cheap foreign funds, households consume these funds during the transitional process and their short-run welfare increases.

Our fourth result says that due to financial frictions, the land price overshoots in the short run and the resulting macroeconomic fluctuation is large if financial liberalization is implemented hastily. Intuitively, the announcement of financial deregulation induces domestic agents to increase their land holding immediately, because they anticipate a higher land price in the future. The rise in the land price improves entrepreneurial net worth contemporaneously. If the public financial regulator implements the deregulation policy hastily, the inflow of cheap foreign funds into the domestic credit market increases immediately and the domestic interest rate declines dramatically. The improvement in entrepreneurial net worth and the decline in the domestic interest rate jointly amplify the land investment of entrepreneurs. Thus, the land price overshoots in the sense that its immediate response exceeds its new long-run level. While, in the case of a gradual implementation, the inflow of cheap foreign funds does not increase so much immediately. The excess investment demand of entrepreneurs pushes up the domestic interest rate. The rise in the domestic interest rate indeed curbs the excess land investment of entrepreneurs. Thus, the land price does not overshoot and the resulting macroeconomic fluctuations are smaller in the case of a gradual implementation than in the case of a hasty implementation.

The rest of this paper is organized as follows. Section 2 describes the model. Section 3 discusses the long-run implications of financial liberalization. Section 4 analyzes the transitional dynamics of financial liberalization. Section 5 summarizes the main findings.

\section{The Model}

Consider a small, open, real economy. There are three domestic goods: a durable asset (land) with a fixed total supply, $K$, an intermediate good, and a final good. There are two types of domestic private agents with infinite numbers: households and entrepreneurs, each of unit mass. There is a public financial regulator and a continuum of foreign lenders.

Households are risk averse and infinitely lived. In each period, they have a safe backyard project to produce intermediate goods using land as the only input; they are endowed with one unit of labor that can be supplied to the production of final goods. Entrepreneurs are risk neutral and each has a constant probability of death. In each period, entrepreneurs of mass $(1-\pi)$ exit from the economy and new entrepreneurs of the same mass are born, keeping the population size of entrepreneurs constant. The newcomers and the surviv- 
ing entrepreneurs supply their labor endowment to the production of final goods. ${ }^{1}$ They have two available projects for the production of intermediate goods using both land and final goods as inputs. Both projects are subject to idiosyncratic risk: projects have positive output in the case of success and there is no output in the case of failure. Each entrepreneur can choose only one project and his project choice is unobservable to others. It takes one period for domestic agents to complete their projects. Land does not depreciate, while the input of final goods fully depreciates during the project process. Intermediate goods are country-specific and only used for the domestic production of final goods. Thus, there is no foreign trade in intermediate goods. Final goods can be either consumed, or invested, or exported.

The project that entrepreneurs choose in equilibrium is more productive than the household project. Mutual funds accept deposits from households and provide loans to entrepreneurs. A deposit contract is a claim on the financial position of the mutual funds. Thus, there are two types of domestic assets: a physical asset (land) and a financial asset (deposit). The foreign lenders are risk neutral and supply funds inelastically at a constant rate of $r^{*}$. The public financial regulator determines the degree of financial openness, defined in subsection 2.1 .

The final good is chosen as the numeraire. Land is traded at the price $q_{t}$ on the spot market. Let $v_{t}, w_{t}$, and $w_{t}^{e}$ denote the price of the intermediate good, the wage rates of households and entrepreneurs, respectively. The domestic interest rate $r_{t}$ is the expected rate of return on the mutual funds. For simplicity, we assume that the foreign interest rate is always smaller than the domestic interest rate around the steady state, $r^{*}<r_{t}$.

\subsection{Asset-Backed Foreign Borrowing}

The mutual funds have the exclusive technology to perfectly verify the project outcomes of domestic agents and to liquidate the land stock of failed projects of entrepreneurs at no discount. As foreign lenders do not have such verification technology. domestic agents cannot credibly pledge their project output to foreign lenders. However, they can borrow abroad against their domestic assets. Normally, foreign lenders are less familiar with the domestic asset market and would incur larger costs in liquidating collateral assets in the event of debtors' default than domestic agents. Furthermore, the domestic legal system is biased against foreign lenders. Either way, foreign borrowing has to be overcollateralized in the following sense. In period $t$, each unit of land is expected to have the value of

\footnotetext{
${ }^{1}$ Each entrepreneur must put a positive amount of own funds in the project in order to acquire loans. Carlstrom and Fuerst (1997) and Bernanke, Gertler, and Gilchrist (1999) adopt the same approach.
} 
$E_{t} q_{t+1}$ in period $t+1$ and domestic agents can pledge only a fraction of the land value, $\theta_{t}^{k} E_{t} q_{t+1}$, to foreign lenders for $\frac{\theta_{t}^{k} E_{t} q_{t+1}}{r^{*}}$ units of final goods, where $\theta_{t}^{k} \in(0,1]$. $\left(1-\theta_{t}^{k}\right)$ can be regarded as a premium that foreign lenders would have to pay to the domestic land buyers when they liquidate the collateralized land. ${ }^{2} \theta_{t}^{k}$ can be affected by many factors, e.g., the efficiency of the domestic legal system, the structure and maturity of domestic market institutions, the tightness of financial regulations, and etc. Thus, $\theta_{t}^{k}$ reflects the degree of foreign lender protection and the effective financial openness.

Similarly, each unit of deposit in period $t$ has an expected return of $r_{t}$ in period $t+1$ and households can pledge only a fraction of the expected deposit return, $\theta_{t}^{d} r_{t}$, to foreign lenders for $\frac{\theta_{t}^{d} r_{t}}{r^{*}}$ units of final goods, where $\theta_{t}^{d} \in(0,1]$. Given that households collectively own the mutual funds, the deposit-backed foreign borrowing essentially enables them to pledge part of the value of the superior verification and liquidation technology of the mutual funds to foreign lenders.

\subsubsection{Two Implementation Strategies of Financial Liberalization}

In order to analyze the policy implications of financial liberalization, we simply assume that $\theta_{t}^{j}$ are perfectly controlled by the public financial regulator and determined at the beginning of each period, where $j \in\{d, k\}$. Financial liberalization may occur due to international or domestic pressures. We focus here on its implications instead of why it occurs. In comparison with monetary policy, financial liberalization is not a day-to-day business and for simplicity, we consider it as an unexpected one-time structural change. Be specific, $\theta_{t}^{j}$ keeps constant and the domestic economy is in its steady state until the public financial regulator decides to change it once for all. For its long-run implications, we investigate the steady state patterns of production efficiency and social welfare under various degrees of financial openness in section 3. For the short-run dynamics, we model financial liberalization as the process in which the public financial regulator raises $\theta^{j}$ either by the big-bang strategy or by the gradualism strategy. In the case of the bigbang strategy, it raises $\theta^{j}$ permanently in period $t$ and keep $\theta^{j}$ constant at the new level afterwards. The big-bang strategy can be modeled as,

$$
\log \theta_{t}^{j}=\log \theta_{t-1}^{j}+\varepsilon_{t}^{j}
$$

where $\varepsilon_{t}^{j}$ denotes the one-time policy change in period $t$. In the case of the gradualism strategy, it announces a path for $\theta^{j}$ gradually reaching the new level over time. The

\footnotetext{
${ }^{2}$ This premium may vary along the business cycle and so does $\theta_{t}^{k}$. See Iacoviello and Minetti (forthcoming) for a detailed discussion.
} 
gradualism strategy can be modeled as,

$$
\begin{aligned}
\log \theta_{t}^{j} & =\log H_{t}^{j}-\log J_{t}^{j}, \\
\log H_{t}^{j} & =\log H_{t-1}^{j}+\varepsilon_{t}^{j}, \\
\log J_{t}^{j} & =\rho \log J_{t-1}^{j}+\varepsilon_{t}^{j},
\end{aligned}
$$

where $\rho$ determines the speed of $\theta^{j}$ approaching to the new level. The one-time policy change $\varepsilon_{t}^{j}$ does not affect $\theta^{j}$ in period $t$, but $\theta^{j}$ grows eventually to the new level. See Gilchrist and Leahy (2002) for the modeling approach. Figure 1 shows the time path of $\theta^{j}$ under the two strategies, given a $1 \%$ positive policy shock in period 0 . A larger $\rho$ in the gradualism strategy implies that it takes longer for $\theta^{j}$ to reach the new level. In section 4 , we set $\rho=0.9$ and compare the short-run effects of the two strategies.
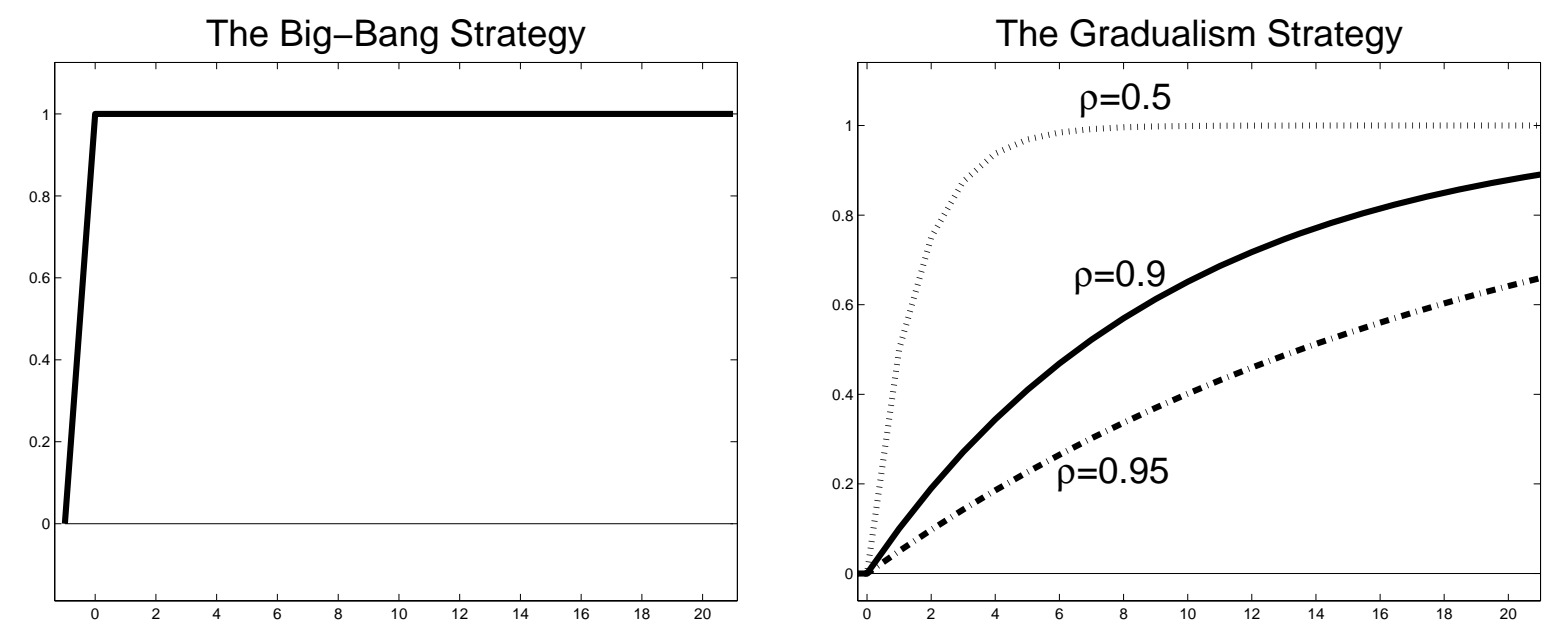

Figure 1: The Policy Paths of The Two Strategies

\subsubsection{Financial Contracts between Entrepreneurs and Foreign Lenders}

As shown in subsection 2.3, entrepreneurs differ in their end-of-period wealth and are indexed by $i \in[0,1]$. Given $r^{*}<r_{t}$, entrepreneur $i$ prefers to pledge his land stock $k_{i, e}^{e}$ to foreign lenders for $z_{i, t}^{e, *}$ units of final goods before he turns to the mutual funds for domestic loans. The entrepreneur's collateral constraints are binding,

$$
r^{*} z_{i, t}^{e, *}=\theta_{t}^{k} E_{t} q_{t+1} k_{i, t}^{e}
$$

Due to costly state verification, the loan contract with a non-contingent repayment is commonly taken in the literature (Gale and Hellwig, 1985). In our model, the information problem that gives rise to the financial frictions between the entrepreneur and the foreign 
lenders results partly from liquidation costs that are proportional to the ex post land value. In this sense, it is more reasonable to consider the state-contingent repayment than non-contingent repayment. Since the entrepreneur and the foreign lenders are risk neutral, the optimal financial contract should let them share unexpected changes in the land price proportionally. In other words, it involves the split of capital gains (losses) between the contracting parties. If the public financial regulator does not change $\theta^{j}$, there will not be any capital gains (losses). Even if the public financial regulator changes $\theta^{j}$, capital gains (losses) only occur at the date of announcement. Thus, the difference in the repayment form does not change our results qualitatively.

In period $t+1$, the foreign lenders get $\theta_{t}^{k} q_{t+1} k_{i, t}^{e}$ units of final goods as repayment and the land has a net value of $\left(1-\theta_{t}^{k}\right) q_{t+1} k_{i, t}^{e}$ to the entrepreneur. For foreign lenders, the ex post rate of return on the entrepreneur's land-backed foreign borrowing is

$$
r_{t+1}^{e, *}=r^{*}\left[1+\frac{q_{t+1}-E_{t} q_{t+1}}{E_{t} q_{t+1}}\right] .
$$

\subsubsection{Financial Contracts between Households and Foreign Lenders}

Given $r^{*}<r_{t}$, households prefer to borrow cheap foreign funds and deposit at the mutual funds to take advantage of the interest rate differential. They borrow $z_{t}^{h, *}$ units of final goods abroad against their land stock $k_{t}$ and borrow $z_{t}^{d, *}$ units of final goods abroad against their deposits $d_{t}$ in period $t$. Their collateral constraints are binding in equilibrium,

$$
\begin{aligned}
& r^{*} z_{t}^{h, *}=\theta_{t}^{k} E_{t} q_{t+1} k_{t}, \\
& r^{*} z_{t}^{d, *}=\theta_{t}^{d} r_{t} d_{t} .
\end{aligned}
$$

As households are risk averse and foreign lenders are risk neutral, the optimal financial contract should perfectly insure households against unexpected changes in the land price and the deposit returns. Foreign lenders get $q_{t+1} k_{t}-\left(1-\theta_{t}^{k}\right) E_{t} q_{t+1} k_{t}$ as repayment on the household land-backed foreign borrowing and the land has a safe net value of $\left(1-\theta_{t}^{k}\right) E_{t} q_{t+1} k_{t}$ to households in period $t+1$. For foreign lenders, the ex post rate of return on the household land-backed foreign borrowing is

$$
r_{t+1}^{h, *}=r^{*}\left(1+\frac{q_{t+1}-E_{t} q_{t+1}}{\theta_{t}^{k} E_{t} q_{t+1}}\right) .
$$

Similarly, foreign lenders get $\tilde{r}_{t+1} d_{t}-\left(1-\theta_{t}^{d}\right) r_{t} d_{t}$ as repayment on the household depositbacked foreign borrowing and the deposits have a safe net value of $\left(1-\theta_{t}^{d}\right) r_{t} d_{t}$ for households in period $t+1$, where $\tilde{r}_{t}$ is the ex post rate of return on mutual funds in period $t$. 
By definition, $r_{t}=E_{t} \tilde{r}_{t+1}$. For foreign lenders, the ex post rate of return on the household deposit-backed foreign borrowing is

$$
r_{t+1}^{d, *}=r^{*}\left(1+\frac{\tilde{r}_{t+1}-r_{t}}{\theta_{t}^{d} r_{t}}\right)
$$

\subsection{Households}

Households have identical preferences over consumption and leisure,

$$
E_{0} \sum_{t=0}^{\infty} \beta^{t}\left[\frac{c_{t}^{1-\sigma}}{1-\sigma}+\chi \frac{\left(1-l_{t}\right)^{1+\psi}}{1+\psi}\right]
$$

where $\beta \in(0,1)$ denotes the time discount factor. $c_{t}$ and $l_{t}$ denote household consumption and labor supply in period $t$, respectively.

Given that $k_{t-1}$ units of land were invested in the household project in period $t-$ $1, G\left(k_{t-1}\right)$ units of intermediate goods are produced at the beginning of period $t$ and household sales revenues amount to $v_{t} G\left(k_{t-1}\right)$.

Assumption 1. The household project is decreasing-return-to-scale, $G^{\prime}(k)>0$ and $G^{\prime \prime}(k)<0$.

Given that households borrowed $z_{t-1}^{h, *}$ abroad against their land stock $k_{t-1}$ in period $t-1$, the land stock has a safe net value of $\left(1-\theta_{t-1}^{k}\right) E_{t-1} q_{t} k_{t-1}$ to households in period $t$. Given that households deposited $d_{t-1}$ at the mutual funds and borrowed $z_{t-1}^{d, *}$ against the expected deposit returns in period $t-1$, the deposits have a safe net value of $(1-$ $\left.\theta_{t-1}^{d}\right) r_{t-1} d_{t-1}$ to households in period $t$. The household wage income is $w_{t} l_{t}$. At the end of period $t$, households consume $c_{t}$, invest $k_{t}$ units of land, deposit $d_{t}$, borrow $z_{t}^{h, *}$ and $z_{t}^{d, *}$ abroad against their land and deposits, respectively.

According to equation (3), households can borrow $\frac{\theta_{t}^{k} E_{t} q_{t+1}}{r^{*}}$ units of final goods abroad against each unit of land invested in period $t$. The household unit down payment is defined as the amount of own funds they pay for a unit of land, $u_{t}=q_{t}-\frac{\theta_{t}^{k} E_{t} q_{t+1}}{r^{*}}$. According to equation (4), households can borrow $\frac{\theta_{t}^{d} r_{t}}{r^{*}}$ units of final goods abroad against each unit of domestic deposit in period $t$. Thus, the household net deposits amount to $\left(1-\frac{\theta_{t}^{d} r_{t}}{r^{*}}\right) d_{t}$. The household flow-budget constraints are,

$$
\begin{aligned}
\left(q_{t}-\frac{\theta_{t}^{k} E_{t} q_{t+1}}{r^{*}}\right) k_{t}+c_{t}+\left(1-\frac{\theta_{t}^{d} r_{t}}{r^{*}}\right) d_{t}= & \left(1-\theta_{t-1}^{k}\right) E_{t-1} q_{t} k_{t-1}+v_{t} G\left(k_{t-1}\right) \\
& +\left(1-\theta_{t-1}^{d}\right) r_{t-1} d_{t-1}+w_{t} l_{t}
\end{aligned}
$$

The optimization over $\left\{c_{t}, l_{t}, d_{t}, k_{t}\right\}$ gives the equilibrium conditions, 


$$
\begin{aligned}
w_{t} & =\chi\left(1-l_{t}\right)^{\psi} c_{t}^{\sigma}, \\
\left(\frac{1}{r_{t}}-\frac{\theta_{t}^{d}}{r^{*}}\right) & =\beta\left(1-\theta_{t}^{d}\right) E_{t}\left(\frac{c_{t+1}}{c_{t}}\right)^{-\sigma}, \\
q_{t}-\frac{\theta_{t}^{k} E_{t} q_{t+1}}{r^{*}} & =\beta E_{t}\left[\left(1-\theta_{t}^{k}\right) q_{t+1}+v_{t+1} G^{\prime}\left(k_{t}\right)\right]\left(\frac{c_{t+1}}{c_{t}}\right)^{-\sigma} .
\end{aligned}
$$

\subsection{Entrepreneurs}

Each entrepreneur can choose one of the two projects: "Good" or "Bad", at the end of each period and his project choice is irreversible. Both projects have the same Leontief technology, i.e., $a$ units of final goods are required for each unit of land invested. ${ }^{3}$ At the beginning of the next period, the project produces $R$ units of intermediate goods per unit of land invested if it succeeds; there is no output if it fails. The two projects provide the entrepreneur with safe, non-pecuniary private benefits ${ }^{4}$ during the project process. For convenience of aggregation, we assume that private benefits are proportional to the amount of land invested. Project "Good" ("Bad") has a probability of success $p^{G}\left(p^{B}\right)$ and provides entrepreneurs with private benefits $b^{G}\left(b^{B}\right)$ per unit of land invested, where $0<p^{B}<p^{G}<1$ and $b^{B}>b^{G}>0$. In other words, project "Good" is safer than projects "Bad", but entrepreneurs get larger unit private benefits from project "Bad".

As shown below, entrepreneurs differ in their end-of-period wealth and are indexed by $i \in[0,1]$. The expected utility function of entrepreneur $i$ is,

$$
E_{0} \sum_{t=0}^{\tilde{T}} \beta^{t}\left[c_{i, t}^{e}+\mathcal{B} k_{i, t-1}^{e}\right]
$$

where $\tilde{T}$ is the stochastic time of death and $\mathcal{B} \in\left\{b^{G}, b^{B}\right\}$ denotes private benefits per unit of land invested in project "Good" or project "Bad". $c_{i, t}^{e}$ denotes his consumption in period $t$ and $k_{i, t-1}^{e}$ denotes his land stock invested in period $t-1$.

\footnotetext{
${ }^{3}$ In models with collateral constraints à la Kiyotaki and Moore (1997), the leverage ratio of borrowers, defined as the ratio of total investment over own funds, is equal to the inverse of the gross interest rate, which is too high and cannot be justified by the empirical data. We introduce the input of final goods to reduce the leverage ratio of entrepreneurs to the reasonable level, e.g., two.

${ }^{4}$ Our set-up resembles the principal-agent setting in Holmstrom and Tirole (1997, 1998). According to Hart (1995), private benefits may refer to any nonpecuniary benefits from running a project, e.g., large offices or luxury business cars. Private benefits are good for the project owners but may reduce the success probability of projects. The trade-off between the success probability and private benefits is a short-cut to capture the divergent objectives between the project owners and the outside financiers.
} 
Our calibration guarantees that only project "Good" has a positive expected net present value around the steady state,

$$
E_{t}\left[\frac{p^{G} R v_{t+1}+\left(1-\theta_{t}^{k}\right) q_{t+1}}{r_{t}}+\frac{\theta_{t}^{k} q_{t+1}}{r^{*}}\right]>q_{t}+a>E_{t}\left[\frac{p^{B} R v_{t+1}+\left(1-\theta_{t}^{k}\right) q_{t+1}}{r_{t}}+\frac{\theta_{t}^{k} q_{t+1}}{r^{*}}\right] .
$$

Therefore, project "Bad" should not be financed in equilibrium. In addition, our calibration guarantees that the expected rate of return on project "Good" exceeds that of the household project even in the case of $k_{t}=0$,

$$
\frac{E_{t}\left[\frac{p^{G} R v_{t+1}+\left(1-\theta_{t}^{k}\right) q_{t+1}}{r_{t}}+\frac{\theta_{t}^{k} q_{t+1}}{r^{*}}\right]}{q_{t}+a}>\frac{E_{t}\left[\frac{v_{t+1} G^{\prime}(0)+\left(1-\theta_{t}^{k}\right) q_{t+1}}{r_{t}}+\frac{\theta_{t}^{k} q_{t+1}}{r^{*}}\right]}{q_{t}} .
$$

Thus, if the project choice of entrepreneurs were perfectly observable, entrepreneurs could borrow against all outcomes of project "Good" and all land would be allocated to them.

At the end of period $t$, the entrepreneur invests $k_{i, t}^{e}$ units of land and $a k_{i, t}^{e}$ units of final goods into either project "Good" or project "Bad", using his own funds, $n_{i, t}$, foreign loans, $z_{i, t}^{e, *}$, and domestic loans, $z_{i, t}^{m}$. Thus, $n_{i, t}=\left(q_{t}+a\right) k_{i, t}^{e}-\left(z_{i, t}^{e, *}+z_{i, t}^{m}\right)$ is the entrepreneur's net worth in the project. The land-backed foreign borrowing contract has been specified in subsection 2.1.2. As the mutual funds cannot observe the project choice of the entrepreneur, the domestic loan contract resembles the standard loan contract (Gale and Hellwig, 1985) and specifies a promise to repay $R_{t}^{m} k_{i, t}^{e}$ units of final goods in period $t+1$ if the project succeeds. As the mutual funds can perfectly verify the project output, the entrepreneur always repays the promised amount if he is able to do so. If the project fails, the entrepreneur hands over his land stock to mutual funds. After repaying the amount owed by the entrepreneur to foreign lenders, mutual funds keep the rest $\left(1-\theta_{t}^{k}\right) q_{t+1} k_{i, t}^{e}$. In order to motivate the entrepreneur to choose project "Good", the mutual funds must provide him with enough incentives,

$$
\left\{p^{G} E_{t}\left[R v_{t+1}+\left(1-\theta_{t}^{k}\right) q_{t+1}-R_{t}^{m}\right]+b^{G}\right\} k_{i, t}^{e} \geq\left\{p^{B} E_{t}\left[R v_{t+1}+\left(1-\theta_{t}^{k}\right) q_{t+1}-R_{t}^{m}\right]+b^{B}\right\} k_{i, t}^{e} .
$$

The left (right) hand side denotes the expected utility of the entrepreneur if he chooses project "Good" ("Bad"). As the expected rate of return on project "Good" exceeds the domestic interest rate, the entrepreneur prefers to borrow to the limit. The incentive constraints are binding around the steady state and can be simplified to,

$$
R_{t}^{m}=E_{t}\left[R v_{t+1}+\left(1-\theta_{t}^{k}\right) q_{t+1}\right]-\tilde{b}, \quad \text { where } \quad \tilde{b} \equiv \frac{b^{B}-b^{G}}{p^{G}-p^{B}}>0 .
$$

Each unit of land invested in project "Good" in period $t$ has an expected value of $E_{t}\left(p^{G} R v_{t+1}+q_{t+1}\right)$ in period $t+1$, in which $\theta_{t}^{k} E_{t} q_{t+1}$ is pledged to foreign lenders first. 
Any promise to repay more than $R_{t}^{m} k_{t}^{e}$ to the mutual funds in the case of success would violate the incentive constraints and is not credible. Thus, the entrepreneur can only pledge $p^{G} R_{t}^{m}+\left(1-p^{G}\right)\left(1-\theta_{t}^{k}\right) E_{t} q_{t+1}$ per unit of land invested to the mutual funds in period $t . E_{t}\left(p^{G} R v_{t+1}+q_{t+1}\right)$ and $p^{G}\left(R_{t}^{m}+\theta_{t}^{k} E_{t} q_{t+1}\right)+\left(1-p^{G}\right) E_{t} q_{t+1}$ are the expected full unit value and external unit value of the land invested in project "Good", respectively. The difference between the two values, $p^{G} \tilde{b}$, is used to motivate the entrepreneur to choose project "Good" despite the lower private benefits it promises, $b^{G}<b^{B}$.

The mutual funds are expected to break even in period $t, r_{t} z_{i, t}^{m}=\left[p^{G} R_{t}^{m}+\left(1-p^{G}\right)(1-\right.$ $\left.\left.\theta_{t}^{k}\right) E_{t} q_{t+1}\right] k_{i, t}^{e}$. It implies a credit constraint for the entrepreneur,

$$
z_{i, t}^{m}=\Gamma_{t} n_{i, t}, \quad \text { where } \quad \Gamma_{t} \equiv \frac{\frac{p^{G}\left(R E_{t} v_{t+1}-\tilde{b}\right)+\left(1-\theta_{t}^{k}\right) E_{t} q_{t+1}}{r_{t}}}{\left(q_{t}+a\right)-\frac{\theta_{t}^{k} E_{t} q_{t+1}}{r^{*}}-\frac{p^{G}\left(R E_{t} v_{t+1}-\tilde{b}\right)+\left(1-\theta_{t}^{k}\right) E_{t} q_{t+1}}{r_{t}}} .
$$

$\Gamma_{t}$ is the domestic credit multiplier. As we are interested in the case where entrepreneurs finance their projects using both own funds and external funds, our calibration guarantees that the denominator in the definition of $\Gamma_{t}$ is positive around the steady state; otherwise, entrepreneurs can finance their projects using external funds only. As $\Gamma_{t}$ is independent of $n_{i, t}$, domestic loans are proportional to the entrepreneur's net worth.

Suppose that entrepreneurs financed their project investment using foreign and domestic loans in period $t-1$. At the beginning of period $t$, entrepreneurs of mass $p^{G}$ have successful projects and entrepreneurs of mass $\left(1-p^{G}\right)$ have failed projects. After the project completion, entrepreneurs of mass $\pi \in(0,1)$ receive a signal of survival and the rest have to exit from the economy.

Entrepreneurs who have successful projects and receive the signal of death are of mass $p^{G}(1-\pi)$. They repay their liabilities, sell off their assets, consume all proceeds, and exit from the economy. Entrepreneurs who have failed projects and receive the signal of death are of mass $\left(1-p^{G}\right)(1-\pi)$. They hand over their land stock to the mutual funds and exit from the economy without consumption.

The newcomers and the surviving entrepreneurs are endowed with a unit of labor and in equilibrium, they supply their labor endowment inelastically $l_{t}^{e}=1$ to the production of final goods and their wage income is $w_{t}^{e}$. At the end of period $t$, the entrepreneur maximizes his expected utility function, subject to his foreign borrowing constraints specified in equation (1), his period-budget constraints, and domestic credit constraints,

$$
\begin{aligned}
\left(q_{t}+a\right) k_{i, t}^{e} & =n_{i, t}+z_{i, t}^{m}+z_{i, t}^{e, *} \quad \text { where } \quad n_{i, t} \equiv \mathcal{N}_{i, t}-c_{i, t}^{e}, \\
z_{i, t}^{m} & =\Gamma_{t} n_{i, t}
\end{aligned}
$$


where $\mathcal{N}_{i, t}$ denotes his end-of-period wealth. The newcomers and entrepreneurs who have failed projects and survive to the next period are of mass $(1-\pi)+\left(1-p^{G}\right) \pi$ and their end-of-period wealth is $\mathcal{N}_{i, t}=w_{t}^{e}$; entrepreneurs who have successful projects and survive to the next period are of mass $p^{G} \pi$ and their end-of-period wealth is $\mathcal{N}_{i, t}=$ $w_{t}^{e}+\left[R v_{t}+\left(1-\theta_{t-1}^{k}\right) q_{t}-R_{t-1}^{m}\right] k_{i, t-1}^{e}$. As the marginal rate of return on project "Good" exceeds the foreign and domestic interest rates, entrepreneurs invest all wealth, borrow to the limit, and postpone consumption to the period of death. It also justifies the fact that the newcomers and the surviving entrepreneurs supply all of their labor endowment.

Due to linear technologies and preferences, the foreign loans, domestic loans, and project investment of entrepreneur $i$ are proportional to his net worth. As a result, only the first moment of the distribution of entrepreneurial net worth matters for the aggregate land stock in the entrepreneur sector. Let lower-case letters without the index $i$ denote per capita variables of entrepreneurs. Per capita consumption $c_{t}^{e}$, net worth $n_{t}$, domestic loans $z_{t}^{m}$, foreign borrowing, $z_{t}^{e, *}$, and land holding $k_{t}^{e}$ of entrepreneurs are

$$
\begin{aligned}
c_{t}^{e} & =(1-\pi) p^{G}\left[R v_{t}+\left(1-\theta_{t-1}^{k}\right) q_{t}-R_{t-1}^{m}\right] k_{t-1}^{e}, \\
n_{t} & =\pi p^{G}\left[R v_{t}+\left(1-\theta_{t-1}^{k}\right) q_{t}-R_{t-1}^{m}\right] k_{t-1}^{e}+w_{t}^{e}, \\
z_{t}^{m} & =\frac{\left[p^{G}\left(R E_{t} v_{t+1}-\tilde{b}\right)+\left(1-\theta_{t}^{k}\right) E_{t} q_{t+1}\right] k_{t}^{e}}{r_{t}}, \\
z_{t}^{e, *} & =\frac{\theta_{t}^{k} E_{t} q_{t+1} k_{t}^{e}}{r^{*}} \\
k_{t}^{e} & =\frac{n_{t}+z_{t}^{e, *}+z_{t}^{m}}{q_{t}+a} .
\end{aligned}
$$

We introduce three auxiliary variables. The first is the entrepreneur unit down payment, defined as the amount of own funds the entrepreneur pays for a unit of land and the required input of final goods, $u_{t}^{e}=\frac{n_{i, t}}{k_{i, t}^{e}}=\left(q_{t}+a\right)-\frac{\theta_{t}^{k} E_{t} q_{t+1}}{r^{*}}-\frac{p^{G}\left(R E_{t} v_{t+1}-\tilde{b}\right)+\left(1-\theta_{t}^{k}\right) E_{t} q_{t+1}}{r_{t}}$. The second is the leverage ratio, defined as the ratio of total investment over the entrepreneur's net worth, $\Omega_{t} \equiv \frac{\left(q_{t}+a\right) k_{i, t}^{e}}{n_{i, t}}=\frac{q_{t}+a}{u_{t}^{e}}$. The third is the profitability of project "Good", defined as the expected gross rate of return on the entrepreneur's net worth, $\xi_{t} \equiv \frac{p^{G} E_{t}\left[R v_{t+1}+\left(1-\theta_{t}^{k}\right) q_{t+1}-R_{t}^{m}\right] k_{i, t}^{e}}{n_{i, t}}=\frac{p^{G} \tilde{b}}{u_{t}^{e}}$. The three auxiliary variables are independent of the entrepreneurs' net worth. Our calibration guarantees that the profitability of project "Good" exceeds the domestic interest rate around the steady state, $\xi_{t}>r_{t}$. Thus, entrepreneurs supply all labor endowment, invest all own funds into their projects, borrow to the limit, and postpone consumption to the period of death. 


\subsection{Mutual Funds}

Let $K_{t-1}^{e}$ and $Z_{t-1}$ denote the aggregate land stock and domestic borrowing of entrepreneurs at the end of period $t-1$, respectively. The aggregate expected break-even condition of the mutual funds in period $t-1$ is $r_{t-1} Z_{t-1}=\left[p^{G} R_{t-1}^{m}+\left(1-p^{G}\right)\left(1-\theta_{t-1}^{k}\right) E_{t-1} q_{t}\right] K_{t-1}^{e}$. At the beginning of period $t$, the total repayment of entrepreneurs with successful projects is $p^{G} R_{t-1}^{m} K_{t-1}^{e}$; entrepreneurs with failed projects hand over their land stock $\left(1-p^{G}\right) K_{t-1}^{e}$ to the mutual funds. After repaying $\left(1-p^{G}\right) \theta_{t-1}^{k} q_{t} K_{t-1}^{e}$ to the foreign lenders, the mutual funds keep the rest, $\left(1-p^{G}\right)\left(1-\theta_{t-1}^{k}\right) q_{t} K_{t-1}^{e}$.

The loan contract described in subsection 2.3 implicitly provides entrepreneurs with a net unit return, with a positive expected value, $p^{G} \tilde{b}>0$, in period $t-1$. For a successful entrepreneur, the post-repayment return on a unit of land in period $t$ is

$$
R v_{t}+\left(1-\theta_{t-1}^{k}\right) q_{t}-R_{t-1}^{m}=\tilde{b}+R\left(v_{t}-E_{t-1} v_{t}\right)+\left(1-\theta_{t-1}^{k}\right)\left(q_{t}-E_{t-1} q_{t}\right) .
$$

A policy change results in unexpected changes in the prices of land and intermediate goods in period $t, q_{t} \neq E_{t-1} q_{t}$ and $v_{t} \neq E_{t-1} v_{t}$. The expected net return to entrepreneurs, $p^{G} \tilde{b} K_{t-1}^{e}$, absorbs most aggregate risk and the ex post rate of return on mutual funds,

$$
\begin{aligned}
\tilde{r}_{t} & =\frac{\left[p^{G} R_{t-1}^{m}+\left(1-p^{G}\right)\left(1-\theta_{t-1}^{k}\right) q_{t}\right] K_{t-1}^{e}}{Z_{t-1}} \\
& =r_{t-1}\left\{1+\frac{\left(1-p^{G}\right)\left(1-\theta_{t-1}^{k}\right)\left(q_{t}-E_{t-1} q_{t}\right)}{E_{t-1}\left[p^{G}\left(R v_{t}-\tilde{b}\right)+\left(1-\theta_{t-1}^{k}\right) q_{t}\right]}\right\},
\end{aligned}
$$

differs from its expected value $r_{t-1} \equiv E_{t-1} \tilde{r}_{t}$ due to unexpected changes in the price of land. According to our calibration, $1-p^{G}=0.01$, the ex post rate of return on mutual funds and deposits does not differ much from its expected value. Furthermore, as the foreign lenders also bear a fraction of capital gains or losses on the land stock of failed entrepreneurs, the discrepancy between the ex post rate of return on deposits and its expected value decreases in $\theta^{k}$.

\subsection{Final Goods Production and Balance of Payment}

Final goods are produced from intermediate goods and labor in a Cobb-Douglas fashion,

$$
Y_{t}=M_{t}^{\alpha} L_{t}^{\left(1-\alpha-\alpha^{\prime}\right)}\left(L_{t}^{e}\right)^{\alpha^{\prime}}
$$

where $M_{t}, L_{t}$, and $L_{t}^{e}$ denote aggregate inputs of intermediate goods, household labor, and entrepreneur labor. ${ }^{5}$ The inputs are priced by their marginal products,

\footnotetext{
${ }^{5}$ As households and entrepreneurs are each of unit mass, the values of aggregate variables coincide with their per capita values.
} 


$$
\begin{aligned}
v_{t} M_{t} & =\alpha Y_{t}, \\
w_{t} L_{t} & =\left(1-\alpha-\alpha^{\prime}\right) Y_{t}, \\
w_{t}^{e} L_{t}^{e} & =\alpha^{\prime} Y_{t} .
\end{aligned}
$$

The aggregate foreign borrowing, $Z_{t}^{*}=z_{t}^{e, *}+z_{t}^{h, *}+z_{t}^{d, *}$, is backed by domestic assets,

$$
r^{*} Z_{t}^{*}=\theta_{t}^{k} E_{t} q_{t+1} K+\theta_{t}^{d} r_{t} d_{t}
$$

and net exports $N X_{t}$ covers the net interest payment on foreign borrowing,

$$
N X_{t}+Z_{t}^{*}=r_{t}^{e, *} z_{t-1}^{e, *}+r_{t}^{h, *} z_{t-1}^{h, *}+r_{t}^{d, *} z_{t-1}^{d, *}
$$

Assumption 2. $\lim _{s \rightarrow \infty} E_{t}\left(\beta^{s} q_{t+s}\right)=0$.

Assumption 2 helps rule out explosive bubbles in the land price and the economy converges to its steady state along a locally unique equilibrium path after hit by a small policy shock. Without explosive bubbles in the land price, the foreign borrowing backed by land is sustainable and the economy does not run into the problem of Ponzi games.

\subsection{Market Equilibrium}

The markets of intermediate goods, final goods, land, labor, and domestic loans clear,

$$
\begin{aligned}
M_{t} & =G\left(k_{t-1}\right)+p^{G} R k_{t-1}^{e}, \\
Y_{t} & =c_{t}+c_{t}^{e}+a k_{t}^{e}+N X_{t}, \\
K & =k_{t}+k_{t}^{e}, \\
L_{t}^{e} & =l_{t}^{e}=1, \\
L_{t} & =l_{t}, \\
z_{t}^{m} & =d_{t} .
\end{aligned}
$$

Definition 1. Market equilibrium is a set of allocations of households, $\left\{k_{t}, l_{t}, z_{t}^{h, *}, z_{t}^{d, *}, c_{t}\right\}$, and entrepreneurs, $\left\{k_{t}^{e}, l_{t}^{e}, n_{t}, z_{t}^{m}, z_{t}^{e, *}, c_{t}^{e}\right\}$, along with aggregate variables $\left\{M_{t}, Y_{t}, N X_{t}, Z_{t}^{*}\right\}$ and a set of prices $\left\{v_{t}, q_{t}, w_{t}, w_{t}^{e}, r_{t}, \tilde{r}_{t}, r_{t}^{h, *}, r_{t}^{d, *}, r_{t}^{e, *}, R_{t}^{m}\right\}$ satisfying equations (2)- (6), (8)(27), given the exogenous processes $\left\{\theta_{t}^{k}, \theta_{t}^{d}\right\}$.

If land-backed foreign borrowing is not allowed, the market equilibrium is almost same as defined above by setting $\theta^{k}=0$. The only exception is that households have to bear unexpected changes in the land price and their budget constraint are

$$
q_{t} k_{t}+c_{t}+\left(1-\frac{\theta_{t}^{d} r_{t}}{r^{*}}\right) d_{t}=q_{t} k_{t-1}+v_{t} G^{\prime}\left(k_{t-1}\right)+\left(1-\theta_{t-1}^{d}\right) r_{t-1} d_{t-1}+w_{t} l_{t} .
$$


If deposit-backed foreign borrowing is not allowed, the market equilibrium is almost same as defined above by setting $\theta^{d}=0$. The only exception is that households have to bear unexpected changes in the deposit return and their budget constraints are

$$
u_{t} k_{t}+c_{t}+d_{t}=\left(1-\theta_{t-1}\right) E_{t-1} q_{t} k_{t-1}+v_{t} G^{\prime}\left(k_{t-1}\right)+\tilde{r}_{t} d_{t-1}+w_{t} l_{t}
$$

\subsection{Calibration}

As our paper intends to provide a conceptual framework to think about the implications of financial liberalization in a small open economy, we focus here more on its qualitative effects instead of its quantitative relevance. As an analytical solution is not obtainable, we use a numerical example to show the intuition explicitly. We calibrate the model to fulfill certain steady-state conditions in the case of international financial autarky $\left(\theta^{k}=\theta^{d}=0\right)$.

The household project takes the following functional form,

$$
G\left(k_{t}\right)=\frac{\epsilon K}{1+\lambda}\left[1-\left(1-\frac{k_{t}}{K}\right)^{1+\lambda}\right]
$$

and the marginal product, $G^{\prime}\left(k_{t}\right)=\epsilon K\left(1-\frac{k_{t}}{K}\right)^{\lambda}$, is decreasing in the household land holding, where $\lambda=8$. We set $\beta=0.98$ and $\bar{r}^{*}=1.01$ so that the annual domestic and foreign interest rates are $8 \%$ and $4 \%$ in the steady state, respectively. Households have $\log$ utility in consumption, $\sigma=1$, as used in Kiyotaki and Moore (2005). Since we want to emphasize the efficiency gains due to the land reallocation between households and entrepreneurs, we keep household labor supply relatively inelastic, $\psi=-5$, so as to limit the effect of household labor on aggregate output of final goods. We set $\chi=0.39$ so that households work eight hours a day in the production of final goods, $l=\frac{1}{3}$. We set $\alpha=0.36$ and $\alpha^{\prime}=0.00001$ so that the household wage income accounts for nearly $64 \%$ of aggregate output of final goods and the entrepreneur wage income is negligible.

The aggregate land stock is normalized at unity, $K=1$. The surviving probability of entrepreneurs is set at $\pi=\frac{2}{3}$, implying that one-third of entrepreneurs have to exit from the economy each period. $\{R=655, \tilde{b}=1.92, \epsilon=60, a=1.53\}$ are calibrated jointly to satisfy the following conditions in the steady state: the land price is $q=1$; the land stock of entrepreneurs is three times as much as that of households, $\frac{k^{e}}{K}=0.75$; the leverage ratio, $\Omega=2$, implies that entrepreneurs finance half of the their project investments using own funds, as in Bernanke, Gertler, and Gilchrist (1999). 


\section{The Long-Run Effects of Financial Liberalization}

\subsection{Deregulating Deposit-Backed Foreign Borrowing}

Figure 2 shows the steady state values of some variables in the model economy against $\theta^{d}$, given $\theta^{k} \in\{0,0.5,1\}$, respectively. The horizontal axis denotes $\theta^{d} \in[0,1]$. Agg, FG, $\mathrm{EN}$, and $\mathrm{HH}$ refer to aggregate, final goods, entrepreneurs, and households, respectively.
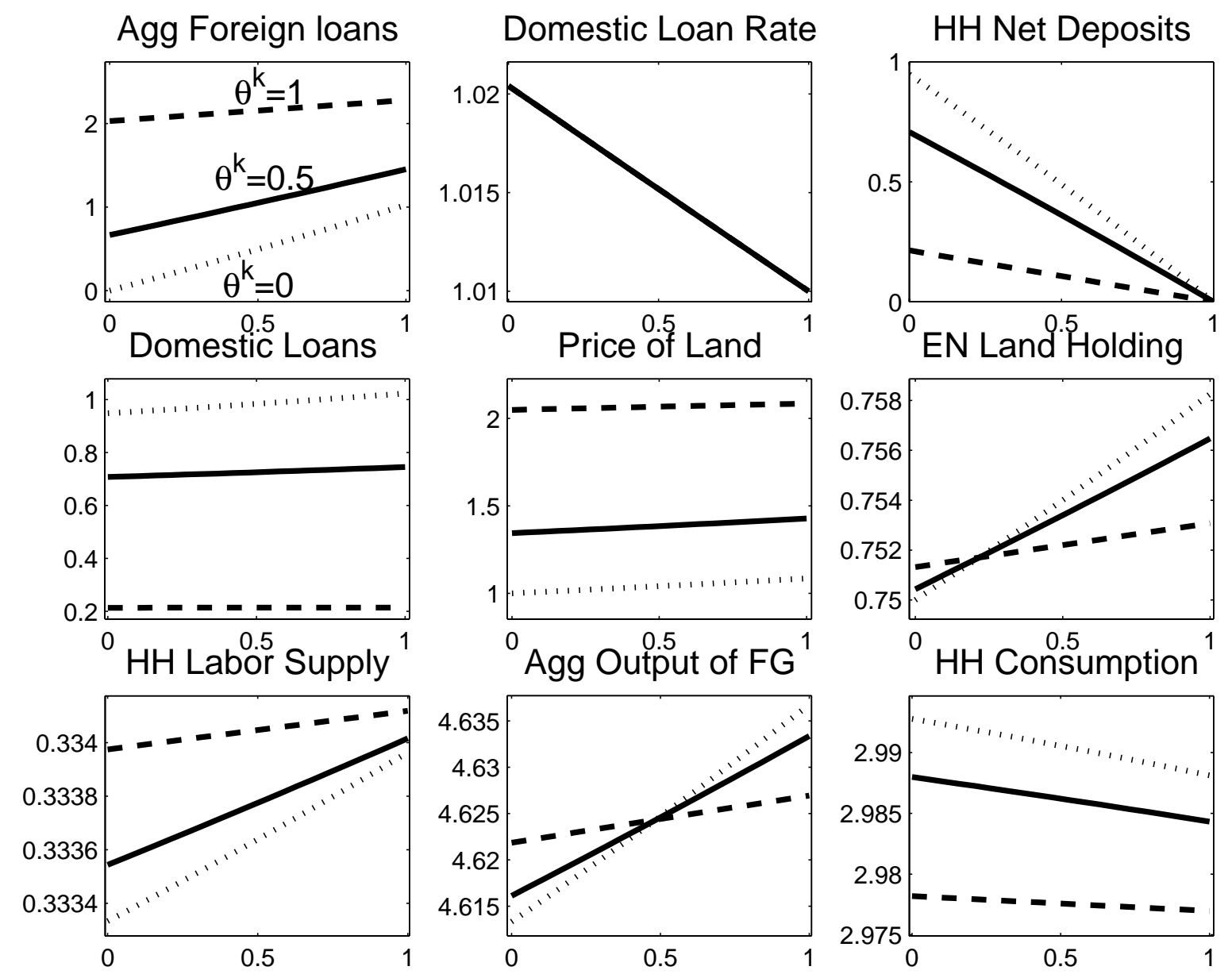

Figure 2: Deregulating Deposit-Backed Foreign Borrowing

Consider the case in which land-backed foreign borrowing is not allowed, $\theta^{k}=0$. See the dotted line. Entrepreneurs can only borrow from the mutual funds and their external funds, $z^{m}=d$, consist of household net deposits, $d-z^{d, *}=\left(1-\frac{\theta^{d} r}{r^{*}}\right) d$, and deposit-backed foreign funds, $z^{d, *}=\frac{\theta^{d} r}{r^{*}} d$. According to equation (9), the rate of return on household net deposits is $\frac{1-\theta^{d}}{\frac{1}{r}-\frac{\theta^{d}}{r^{*}}}=\frac{1}{\beta}$, independent of $\theta^{d}$. The rise in $\theta^{d}$ actually enables households to substitute cheap foreign funds for their net deposits. In the case of $\theta^{d}=1$, households fully pledge their deposits to the foreign lenders and domestic loans to entrepreneurs are 
essentially provided by the foreign lenders only.

As $\theta^{d}$ rises from 0 to 1 , the domestic interest rate, $r=\frac{1}{\beta+\theta^{d}\left(\frac{1}{r^{*}}-\beta\right)}$, declines from $\frac{1}{\beta}$ to $r^{*}$. Intuitively, the increase in the inflow of cheap foreign funds reduces the average cost of loanable funds in the domestic economy. Given $\theta^{k}=0$, entrepreneurs cannot borrow directly abroad. However, the decline in the domestic interest rate due to the rise in $\theta^{d}$ enables entrepreneurs to increase their domestic borrowing and expand their project investment. In this sense, households act as financial intermediaries to channel cheap foreign funds into the domestic economy. Given the fixed aggregate land stock, the rise in the entrepreneurs' demand pushes up the land price. Thus, the entrepreneurs' leverage ratio rises and so does their land holding. As project "Good" is more productive than the household project, aggregate output of intermediate goods rises. In this sense, deregulating deposit-backed foreign borrowing improves production efficiency.

The rise in $\theta^{d}$ has three negative effects on household wealth: the return on household net deposit $\left(1-\theta^{d}\right) r d$ declines in $\theta^{d}$ and so do their land stock and sales revenues of intermediate goods. According to equation (30), the negative wealth effects induce households to increase their labor and reduce consumption. Thus, households lose strictly from deregulating deposit-backed foreign borrowing. While, the entrepreneurs' consumption, which is proportional to their land holding, increases in $\theta^{d}$. Thus, entrepreneurs benefit strictly from deregulating deposit-backed foreign borrowing. Similar patterns can be found in the cases of $\theta^{k}=0.5$ and $\theta^{k}=1$.

\subsection{Deregulating Land-Backed Foreign Borrowing}

Figure 2 shows the steady state values of some endogenous variables in the model economy against $\theta^{k}$, given $\theta^{d} \in\{0,0.5,1\}$, respectively. The horizontal axis denotes $\theta^{k} \in[0,1]$.

Consider first the case in which deposit-backed foreign borrowing is not allowed, $\theta^{d}=$ 0 . See the dotted line. The domestic interest rate is above the foreign interest rate, $r=\frac{1}{\beta}>r^{*}$. The rise in $\theta^{k}$ from 0 to 1 enables domestic agents to borrow more abroad against their land stock. Thus, their demand for land rises and so does the land price. As a larger share of entrepreneurs' external funds is provided directly by the foreign lenders at a rate lower than the domestic rate, the average cost of entrepreneurs' external funds declines significantly in $\theta^{k}$. As a result, the land holding of entrepreneurs rises and so does aggregate output of intermediate goods. In this case, deregulating land-backed foreign borrowing improves production efficiency and has opposite welfare implications to households and entrepreneurs, as discussed in subsection 3.1

Consider now the case in which domestic deposits can be fully pledge to the foreign 

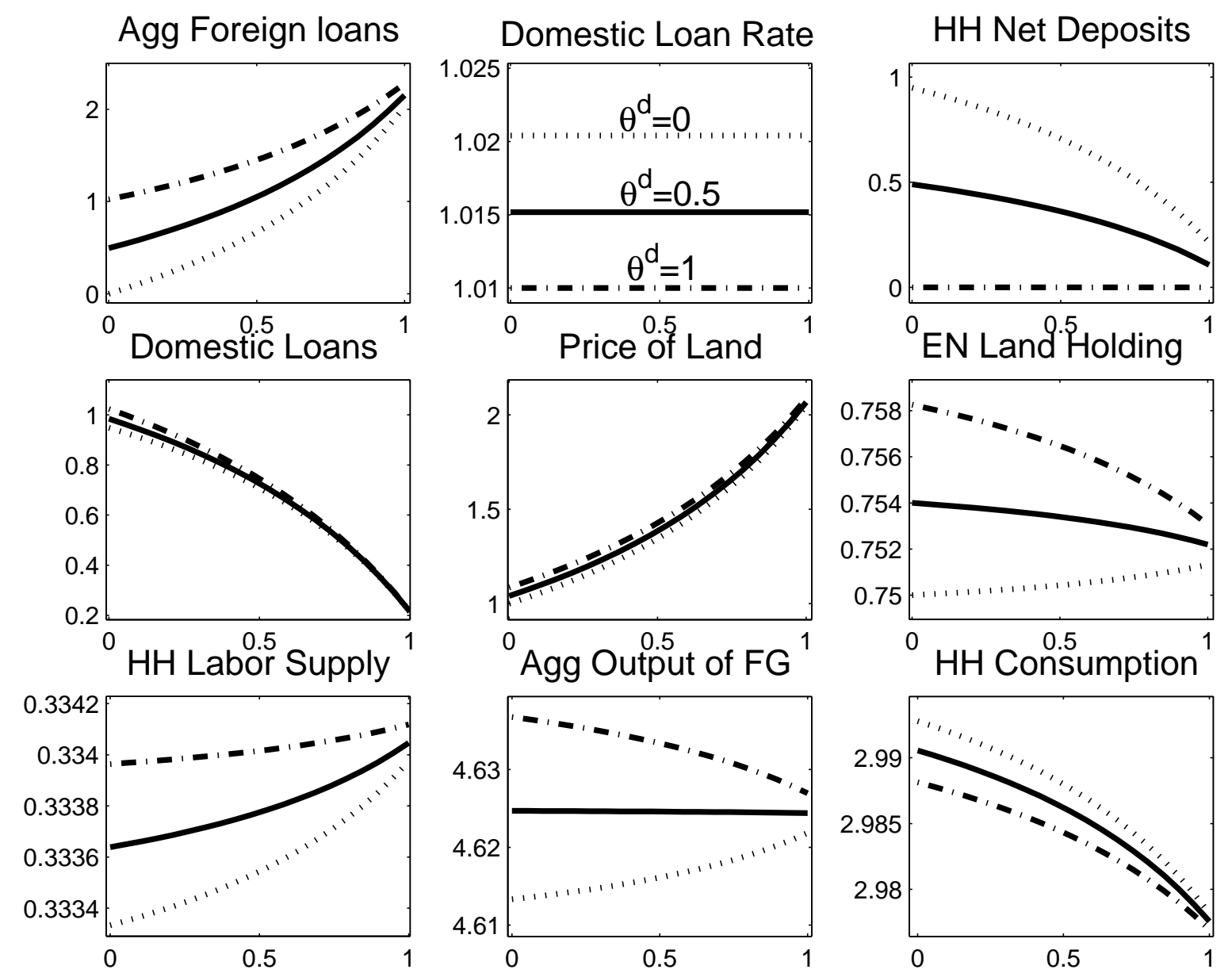

Figure 3: Deregulating Land-Backed Foreign Borrowing

lenders, $\theta^{d}=1$. See the dash-dot line. The domestic interest rate is equal to the foreign rate, $r=r^{*}$ and households actually make zero net deposits. In the case of $\theta^{k}=0$, although entrepreneurs cannot borrow directly abroad, all of their domestic loans are essentially provided by the foreign lenders via the household deposit-backed borrowing. As $\theta^{k}$ rises from 0 to 1 , the cost of entrepreneurs' external funds is constant at $r^{*}$, while households can acquire cheap foreign funds against their land holding. The rise in the household demand for land pushes up the land price and entrepreneurs have to reduce their land stock. In this case, production becomes less efficient.

The net value of the household land stock $\left(1-\theta^{k}\right) q k$ declines in $\theta^{k}$. Due to the negative wealth effect, households have to increase labor and reduce consumption. The unfavorable land reallocation has negative welfare effects on entrepreneurs, too. Therefore, both households and entrepreneurs lose strictly in the long run.

In sum, as financial liberalization is a two-dimensional issue in our model, the so- 
phisticated interaction between its two components, i.e., land-backed and deposit-backed foreign borrowing, complicates its implications to production efficiency and social welfare. Although deregulating land-backed foreign borrowing reduces the average cost of external funds of entrepreneurs, it also reduces the household unit down payment of land. Whether deregulating land-backed foreign borrowing can improve production efficiency actually depends on the relative changes in the cost of external funds of entrepreneurs and households. If deposit-backed foreign borrowing is highly regulated, the domestic interest rate is still quite high. As $\theta^{k}$ rises from 0 to 1 , the average cost of entrepreneurs' external funds declines in a larger magnitude than the cost of household external funds. However, if deposit-backed foreign borrowing is highly deregulated, the domestic interest rate is already very low. As $\theta^{k}$ rises from 0 to 1 , the average cost of entrepreneurs' external funds declines in a smaller magnitude than the cost of household external funds. In contrast, deregulating deposit-backed foreign borrowing has the negative effect on the domestic interest rate, which facilitates the land reallocation towards the more productive agents (entrepreneurs). Thus, if the public financial regulator has the objective to improve production efficiency in the domestic economy, it should deregulate deposit-backed foreign borrowing rather than land-backed foreign borrowing.

\section{The Implementation of Financial Liberalization}

This section discusses how the big-bang strategy and the gradualism strategy can result in macroeconomic fluctuations. Subsection 4.1 compares the dynamics of the model economy to the two strategies of raising $\theta^{d}$ permanently from $50 \%$ to $55 \%$, given that the economy is at its old steady state $\theta^{d}=50 \%$ before period 0 and land-backed foreign borrowing is not allowed $\theta^{k}=0$. Subsection 4.2 compares the dynamics of the model economy to the two strategies of raising $\theta^{k}$ from $50 \%$ to $55 \%$, given that the economy is at its old steady state $\theta^{k}=50 \%$ before period 0 and deposit-backed foreign borrowing is not allowed $\theta^{d}=0$. Endogenous variables are approximated as the linear functions of the state variables in logarithms around the old steady state, which we solve using the MATLAB codes provided by Schmitt-Grohé and Uribe (2004). ${ }^{6}$

\footnotetext{
${ }^{6}$ Section 3 shows that a permanent change in $\theta^{j}$ changes the steady state of the economy. Thus, the dynamic analysis based on the log-linearization at the old steady state could be inaccurate. However, for a small change in $\theta^{j}$, e.g, $10 \%$ here, we can still use first-order approximations to analyze the transitional dynamics from the old steady state to the new steady state.
} 


\subsection{Deregulating Deposit-Backed Foreign Borrowing}

Figure 4 shows the impulse responses of the model economy to the big-bang strategy (dashed line) and the gradualism strategy (solid line) of raising $\theta^{d}$ permanently from $50 \%$ to $55 \%$, given $\theta^{k}=0$.
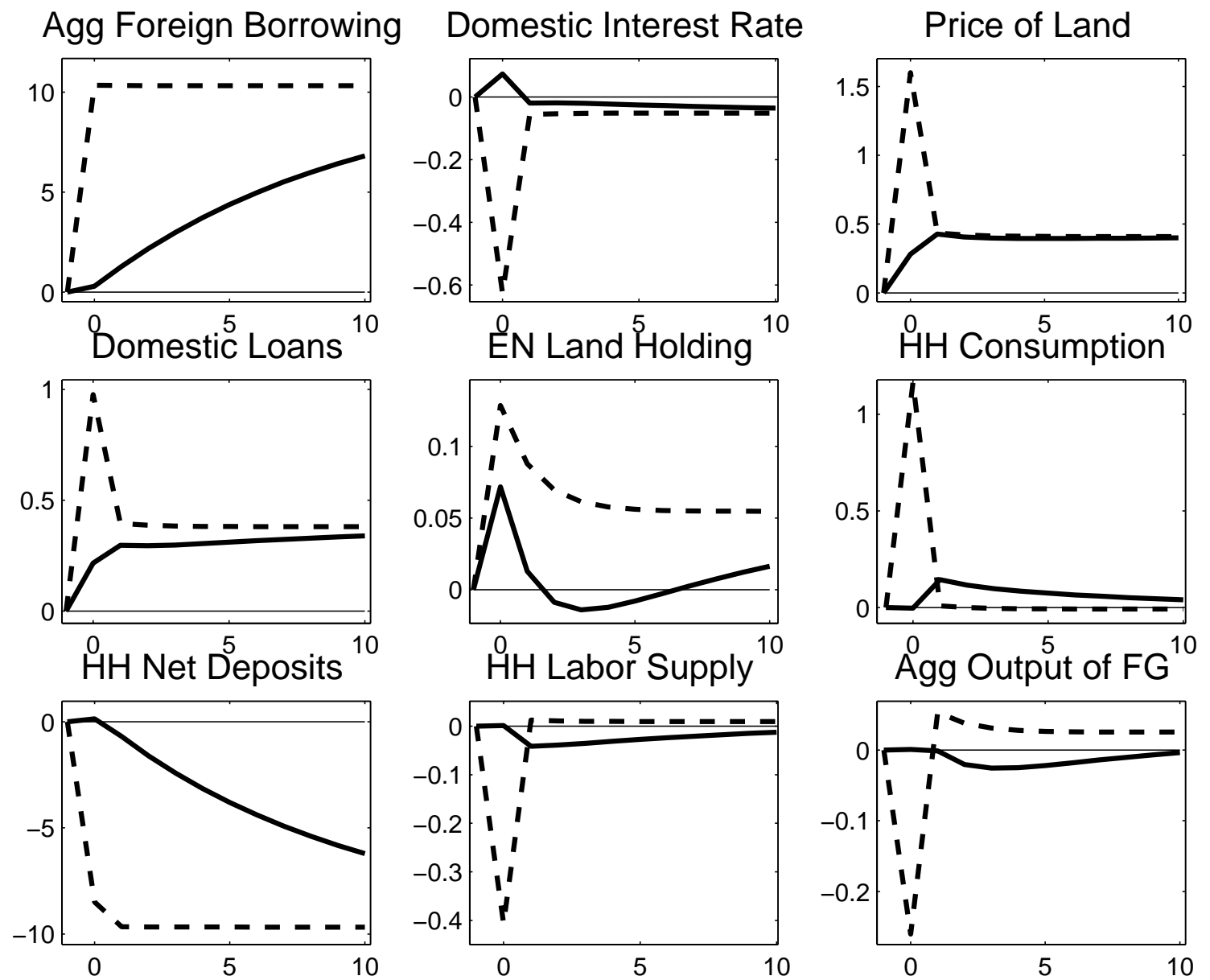

Figure 4: Deregulating Deposit-Backed Foreign Borrowing: Big-Bang vs. Gradualism

Consider the big-bang strategy first. The public financial regulator raises $\theta^{d}$ from $50 \%$ to $55 \%$ permanently from period 0 on. Households can immediately borrow abroad against a larger fraction of their deposits and thus, deposit-backed foreign borrowing rises dramatically in period 0 . The supply effect dominates in the domestic credit market in the sense that the domestic interest rate declines contemporaneously. In the meantime, anticipating a higher land price in the new steady state, domestic agents increase their land demand. Thus, the land price rises in period 0 and the capital gains improve entrepreneurial net worth and household wealth.

The rise in entrepreneurial net worth and the decline in the domestic interest rate 
jointly amplify the entrepreneurs' demand for land and the land price rises to clear the market. The two-way reinforcing interactions between prices and quantities are the inherent feature of models with financial frictions. The land price overshoots in the sense that it rises by $1.6 \%$ in period 0 , much larger than the $0.4 \%$ in the new steady state. This phenomenon is similar as the exchange rate overshooting (Dornbusch, 1976). The overshooting of the land price here results from financial frictions instead of price rigidity.

The positive wealth effect and the decline in the domestic interest rate induces households to increase consumption and reduce net deposits at the mutual funds in period 0 . Anticipating a lower consumption in the new steady state, households prefer to smooth consumption by reducing their net deposits only by $8.5 \%$, smaller than the $9.7 \%$ in the new steady state. As deposit-backed foreign borrowing rises to its new steady state value, aggregate deposits at the mutual funds rise by $0.98 \%$, larger than the $0.38 \%$ in the new steady state. Thus, the excess supply of domestic loans reduces the domestic interest rate by $0.63 \%$, larger than the $0.05 \%$ in the new steady state. The positive wealth effect also induces households to reduce labor and aggregate output of final goods declines in period 0 . As $\theta^{d}$ is constant at its new steady state value from period 0 on, the land price and the domestic interest rate converge fast to their respective new steady state values and so do household consumption and labor supply.

As shown in figure 2, households strictly lose from deregulating deposit-backed foreign borrowing in the long run. Since the domestic interest rate are lower in the new steady state than in the old one, households consume their extra net deposits and their period utility actually rises in period 0 . In this sense, the overall implications of deregulating deposit-backed foreign borrowing to household welfare should be evaluated with the consideration of both short-run and long-run effects.

Consider now the gradualism strategy. The public financial regulator announces the future policy path of $\theta_{t}^{d}$ in period 0 . See figure 1. Anticipating a higher land price in the future, domestic agents increase their demand for land in period 0. Thus, the land price rises in period 0 and the capital gains improve the household wealth and entrepreneurial net worth. As $\theta_{0}^{d}=50 \%$ is still at its old steady state value in period 0 , deposit-backed foreign borrowing does not increase dramatically in period 0 . Therefore, the demand effect dominates in the domestic credit market in the sense that the rise in the entrepreneurs' demand for domestic loans pushes up the domestic interest rate. Although capital gains improve entrepreneurial net worth, the rise in the domestic interest rate curbs the entrepreneurs' demand for domestic loans and land. As a result, the land price rises by $0.28 \%$ in period 0 , smaller than the $0.4 \%$ in the new steady state. In other words, 
the land price does not overshoot in period 0 .

The rise in the domestic interest rate and capital gains have opposite effects on households' decision on consumption and deposit. In equilibrium, households do not change consumption and deposits much in period 0. Due to the consumption-leisure substitution, households do not change their labor supply much in period 0, either. Thus, aggregate output of final goods does not decline as much as in the case of the big-bang strategy.

From period 1 on, $\theta^{d}$ rises gradually to the new steady state value. Due to the increase in deposit-backed foreign borrowing, the domestic interest rate is below the old steady state value in period 1 and converges to the new steady state value from then on. Thus, household consumption rises above the old steady state value in period 1 and converges to the new steady state value that is lower than the old one. In the meantime, household labor supply falls below the old steady state value in period 0 and converges to the new steady state value that is above the old one. The opposite short-run and long-run welfare implications to households are similar as in the case of the big-bang strategy.

The big-bang strategy and the gradualism strategy differ in their effects on the domestic interest rate in period 0 . The big-bang strategy allows the immediate increase in the inflow of cheap foreign funds and the domestic interest rate declines. Given that capital gains improve entrepreneurial net worth in period 0 , the decline in the interest rate further amplify the entrepreneurs' demand for land and the land price overshoot in period 0. In contrast, the gradualism strategy does not allow an immediate increase in the inflow of cheap foreign funds and the domestic interest rate rises to curb the entrepreneurs' demand for domestic loans and land. Thus, the land price does not overshoot. As a result, output, labor, consumption, and net exports respond in a much smaller magnitude to the gradualism strategy than to the big-bang strategy.

\subsection{Deregulating Land-Backed Foreign Borrowing}

Figure 5 shows the impulse responses of the model economy to the big-bang strategy (dashed line) and the gradualism strategy (solid line) of raising $\theta^{k}$ permanently from $50 \%$ to $55 \%$, given $\theta^{d}=0$.

Consider the big-bang strategy first. The public financial regulator raises $\theta^{k}$ from $50 \%$ to $55 \%$ from period 0 on and domestic agents can borrow abroad against a larger fraction of the value of their land holding. Thus, the rise in land-backed foreign borrowing pushes up the land demand in period 0 and the land price rises to clear the market. According to the land-backed financial contracts specified in subsection 2.1, entrepreneurs and the foreign lenders equally share the capital gains on the entrepreneurs' land stock, while the 
Agg Foreign Borrowing Domestic Interest Rate
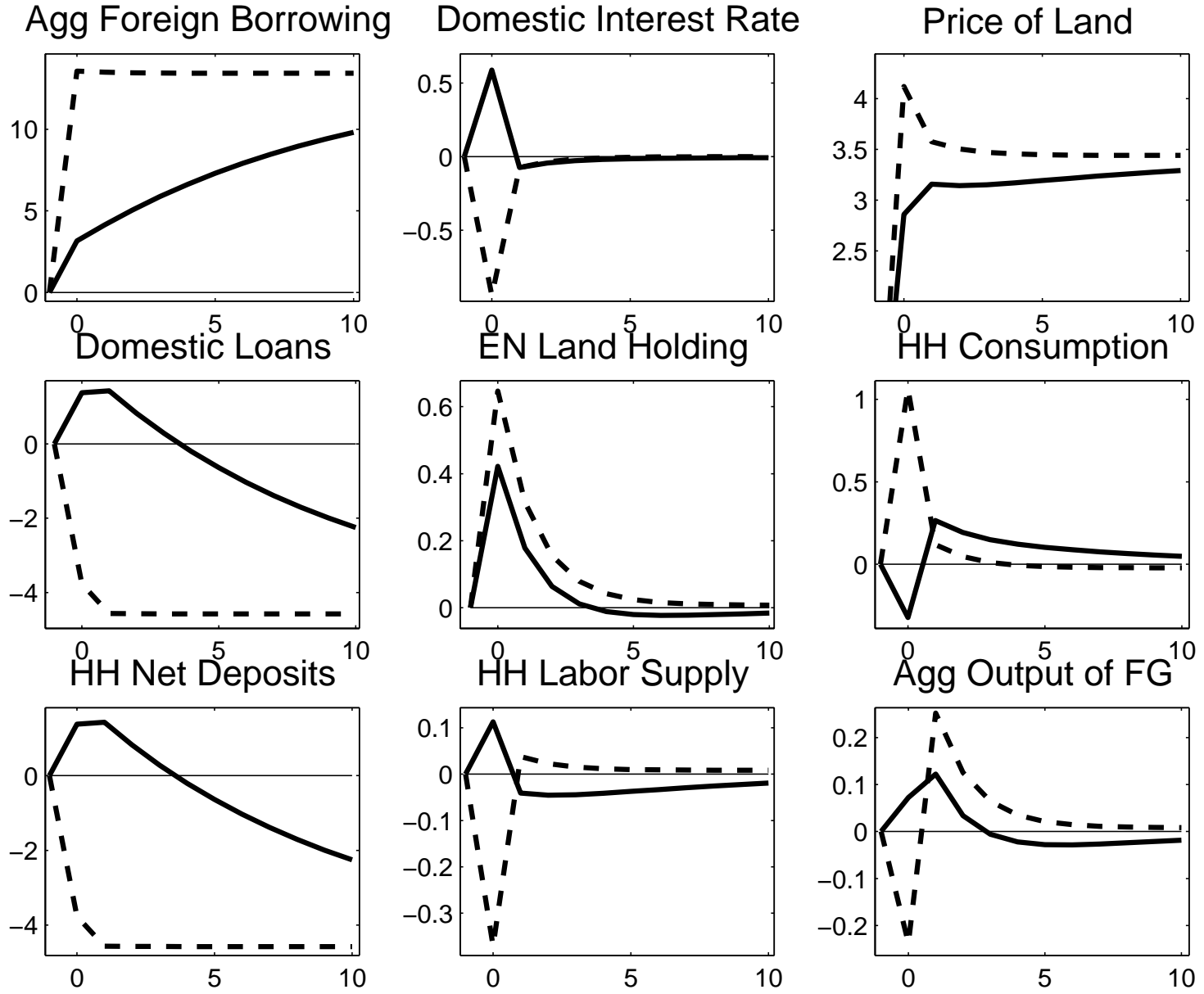

Figure 5: Deregulating Land-Backed Foreign Borrowing: Big-Bang vs. Gradualism

foreign lenders takes all capital gains on the household land stock and the land stock has a safe net value to households. The capital gains improve entrepreneurial net worth and entrepreneurs increase their demand for land over-proportionally. The land price rises further and the spiral process between the land price, entrepreneurial net worth, and the entrepreneurs' demand for land continues. Altogether, the land price overshoots by $4.1 \%$ and the entrepreneurs' land stock rises by $0.65 \%$ in period 0 .

Given that domestic agents finance their land investment using more foreign funds, the entrepreneurs' demand for domestic loans declines in period 0 and so does the domestic interest rate. Thus, households prefer to consume more and deposit less. Anticipating a lower consumption in the new steady state, households prefer to smooth consumption by reducing deposits by $3.76 \%$, smaller than the $4.57 \%$ in the new steady state. The consumption-leisure substitution induces households to reduce labor supply in period 0 and aggregate output of final goods declines.

The rise in the period-0 entrepreneurs' land stock pushes up aggregate output of 
intermediate goods in period 1. Given that household labor supply is very close to its new steady state value since period 1 , aggregate output of final goods exceeds its old steady state value in period 1. Given no more policy shock from period 1 on, macroeconomic aggregates converge to their respective steady state values. Thus, household period utility exceeds its old steady state value in period 0 and converges to its new steady state value.

Consider now the gradualism strategy. The public financial regulator announces the future policy path for $\theta_{t}^{k}$ in period 0 . Anticipating a higher land price in the future, domestic agents increase their demand for land in period 0 and the land price rises to clear the market. Capital gains improve entrepreneurial net worth and entrepreneurs increase their demand for external funds and land. As $\theta_{0}^{k}=50 \%$, entrepreneurs cannot increase their land-backed foreign borrowing dramatically and they increase their demand for domestic loans. Thus, the domestic interest rate rises in period 0. Households reduces consumption and increase labor supply in order to deposit more at the mutual funds for the favorable interest rate. The rise in household labor pushes up aggregate output of final goods in period 0 .

As entrepreneurs can borrow abroad against an increasingly larger fraction of their land value from period 1 on, the entrepreneurs' demand for domestic loans declines and so does the domestic interest rate. Anticipating a lower consumption in the new steady state, households prefer to smooth consumption by further increasing their deposits despite a lower domestic interest rate in period 1 . The increase in the period-0 entrepreneurs' land stock results in the rise in aggregate output of intermediate goods in period 1. Thus, aggregate output of final goods is still above its steady state value in period 1 despite the decline in household labor supply. From period 1 on, macroeconomic aggregates converge to their respective new steady state values.

During the process of the rise in $\theta^{k}$, entrepreneurs substitute land-backed foreign borrowing for domestic loans and thus, households have to reduce their deposits eventually. In other words, the rise in household period utility in the first few periods actually results from the spending of these deposits.

Similarly as in subsection 4.1, macroeconomic aggregates respond to the gradualism strategy in a smaller magnitude than to the big-bang strategy in the case of deregulating land-backed foreign borrowing. 


\section{$5 \quad$ Final Remarks}

This paper provides a conceptual framework for analyzing the macroeconomic implications of financial liberalization in a small, open, real economy. As financial liberalization is a multi-dimensional issue, the sophisticated interactions among its various components complicate the evaluation of specific deregulation policy. Be specific, whether the deregulation policy in one sector can improve production efficiency may depend on the financial regulations in other sectors. Furthermore, the improvement in production efficiency does not necessarily imply a higher welfare for domestic agents. Due to the direct or indirect substitution of foreign loans for domestic loans, domestic lenders strictly suffer from the negative wealth effect in the long run; while domestic borrowers might be able to acquire more domestic productive assets and benefit from financial liberalization in the long run. In this sense, financial liberalization may have opposite long-run welfare implications to domestic agents with different productivity and aggregate output is not a good indicator for social welfare in the model with heterogeneous agents. However, the welfare of domestic lenders may rise during the transitional process because they consume the funds which are substituted by foreign funds. Finally, due to financial frictions, asset prices overshoot and macroeconomic fluctuations are large if financial liberalization is implemented hastily. In contrast, if financial liberalization is implemented gradually, domestic agents have time to adjust to the new policy and a smooth transition can be achieved.

\section{References}

Alessandria, G., AND J. Qian (2005): "Endogenous financial intermediation and real effects of capital account liberalization," Journal of International Economics, 67(1), 97-128.

Aoki, K., G. Benigno, And N. Kiyotaki (2005): "Adjusting to Capital Liberalization," Lecture Notes.

Bernanke, B. S., M. Gertler, And S. Gilchrist (1999): "The Financial Accelerator in a Quantitative Business Cycle Framework," in Handbook of Macroeconomics, ed. by J. Taylor, and M. Woodford, vol. 1C, pp. 1341-1393, north-holland. Elsevier.

Caballero, R. J., And A. Krishnamurthy (2001): "International and Domestic Collateral Constraints in a Model of Emerging Market Crises," Journal of Monetary Economics, 48(3), 513-48.

(2003): "Excessive Dollar Debt: Financial Development and Underinsurance," The Journal of Finance, 58(2), 867-893.

Carlstrom, C. T., AND T. S. Fuerst (1997): "Agency Costs, Net Worth, and Business Fluctuations: A Computable General Equilibrium Analysis," American Economic Review, 87(5), 893-910. 
Dornbusch, R. (1976): "Expectations and Exchange Rate Dynamics," Journal of Political Economy, $84(6), 1161-76$.

Gale, D., And M. Hellwig (1985): "Incentive-Compatible Debt Contracts: The One-Period Problem," Review of Economic Studies, 52(4), 647-63.

Gilchrist, S., AND J. LEAHY (2002): "Monetary policy and asset prices," Journal of Monetary Economics, 49(1), 75-97.

Hart, O. (1995): Firms, Contracts, and Financial Structure. Oxford University Press, Oxford.

Holmstrom, B., AND J. Tirole (1997): "Financial Intermediation, Loanable Funds, and the Real Sector," Quarterly Journal of Economics, 112(3), 663-691.

(1998): "Private and Public Supply of Liquidity," Journal of Political Economy, 106(1), 1-40.

IAcoviello, M., AND R. Minetti (forthcoming): "International Business Cycles with Domestic and Foreign Lenders," Journal of Monetary Economics.

Kiyotaki, N., And J. Moore (1997): “Credit Cycles," Journal of Political Economy, 105(2), 211-48. (2005): "Liquidity and Asset Prices," International Economic Review, 46(2), 317-349.

Schmitt-Grohé, S., AND M. Uribe (2004): "Solving Dynamic General Equilibrium Models Using a Second-Order Approximation to the Policy Function," Journal of Economic Dynamics and Control, $28(1), 755-775$.

Stulz, R. M. (2005): "The Limits of Financial Globalization,” Journal of Finance, 60(4), 1595-1638.

WorldBank (2005): Financial Sector Assessment: A HandBook. World Bank and International Monetary Funds. 


\section{CESifo Working Paper Series}

(for full list see www.cesifo-group.de)

1709 Helge Berger and Stephan Danninger, The Employment Effects of Labor and Product Markets Deregulation and their Implications for Structural Reform, May 2006

1710 Michael Ehrmann and Marcel Fratzscher, Global Financial Transmission of Monetary Policy Shocks, May 2006

1711 Carsten Eckel and Hartmut Egger, Wage Bargaining and Multinational Firms in General Equilibrium, May 2006

1712 Mathias Hoffmann, Proprietary Income, Entrepreneurial Risk, and the Predictability of U.S. Stock Returns, May 2006

1713 Marc-Andreas Muendler and Sascha O. Becker, Margins of Multinational Labor Substitution, May 2006

1714 Surajeet Chakravarty and W. Bentley MacLeod, Construction Contracts (or "How to Get the Right Building at the Right Price?’), May 2006

1715 David Encaoua and Yassine Lefouili, Choosing Intellectual Protection: Imitation, Patent Strength and Licensing, May 2006

1716 Chris van Klaveren, Bernard van Praag and Henriette Maassen van den Brink, Empirical Estimation Results of a Collective Household Time Allocation Model, May 2006

1717 Paul De Grauwe and Agnieszka Markiewicz, Learning to Forecast the Exchange Rate: Two Competing Approaches, May 2006

1718 Sijbren Cnossen, Tobacco Taxation in the European Union, May 2006

1719 Marcel Gérard and Fernando Ruiz, Interjurisdictional Competition for Higher Education and Firms, May 2006

1720 Ronald McKinnon and Gunther Schnabl, China's Exchange Rate and International Adjustment in Wages, Prices, and Interest Rates: Japan Déjà Vu?, May 2006

1721 Paolo M. Panteghini, The Capital Structure of Multinational Companies under Tax Competition, May 2006

1722 Johannes Becker, Clemens Fuest and Thomas Hemmelgarn, Corporate Tax Reform and Foreign Direct Investment in Germany - Evidence from Firm-Level Data, May 2006

1723 Christian Kleiber, Martin Sexauer and Klaus Waelde, Bequests, Taxation and the Distribution of Wealth in a General Equilibrium Model, May 2006 
1724 Axel Dreher and Jan-Egbert Sturm, Do IMF and World Bank Influence Voting in the UN General Assembly?, May 2006

1725 Swapan K. Bhattacharya and Biswa N. Bhattacharyay, Prospects of Regional Cooperation in Trade, Investment and Finance in Asia: An Empirical Analysis on BIMSTEC Countries and Japan, May 2006

1726 Philippe Choné and Laurent Linnemer, Assessing Horizontal Mergers under Uncertain Efficiency Gains, May 2006

1727 Daniel Houser and Thomas Stratmann, Selling Favors in the Lab: Experiments on Campaign Finance Reform, May 2006

1728 E. Maarten Bosker, Steven Brakman, Harry Garretsen and Marc Schramm, A Century of Shocks: The Evolution of the German City Size Distribution 1925 - 1999, May 2006

1729 Clive Bell and Hans Gersbach, Growth and Enduring Epidemic Diseases, May 2006

1730 W. Bentley MacLeod, Reputations, Relationships and the Enforcement of Incomplete Contracts, May 2006

1731 Jan K. Brueckner and Ricardo Flores-Fillol, Airline Schedule Competition: ProductQuality Choice in a Duopoly Model, May 2006

1732 Kerstin Bernoth and Guntram B. Wolff, Fool the Markets? Creative Accounting, Fiscal Transparency and Sovereign Risk Premia, May 2006

1733 Emmanuelle Auriol and Pierre M. Picard, Government Outsourcing: Public Contracting with Private Monopoly, May 2006

1734 Guglielmo Maria Caporale and Luis A. Gil-Alana, Modelling Structural Breaks in the US, UK and Japanese Unemployment Rates, May 2006

1735 Emily J. Blanchard, Reevaluating the Role of Trade Agreements: Does Investment Globalization Make the WTO Obsolete?, May 2006

1736 Per Engström and Bertil Holmlund, Tax Evasion and Self-Employment in a High-Tax Country: Evidence from Sweden, May 2006

1737 Erkki Koskela and Mikko Puhakka, Cycles and Indeterminacy in Overlapping Generations Economies with Stone-Geary Preferences, May 2006

1738 Saku Aura and Thomas Davidoff, Supply Constraints and Housing Prices, May 2006

1739 Balázs Égert and Ronald MacDonald, Monetary Transmission Mechanism in Transition Economies: Surveying the Surveyable, June 2006

1740 Ben J. Heijdra and Ward E. Romp, Ageing and Growth in the Small Open Economy, June 2006 
1741 Robert Fenge and Volker Meier, Subsidies for Wages and Infrastructure: How to Restrain Undesired Immigration, June 2006

1742 Robert S. Chirinko and Debdulal Mallick, The Elasticity of Derived Demand, Factor Substitution and Product Demand: Corrections to Hicks' Formula and Marshall's Four Rules, June 2006

1743 Harry P. Bowen, Haris Munandar and Jean-Marie Viaene, Evidence and Implications of Zipf's Law for Integrated Economies, June 2006

1744 Markku Lanne and Helmut Luetkepohl, Identifying Monetary Policy Shocks via Changes in Volatility, June 2006

1745 Timo Trimborn, Karl-Josef Koch and Thomas M. Steger, Multi-Dimensional Transitional Dynamics: A Simple Numberical Procedure, June 2006

1746 Vivek H. Dehejia and Yiagadeesen Samy, Labor Standards and Economic Integration in the European Union: An Empirical Analysis, June 2006

1747 Carlo Altavilla and Paul De Grauwe, Forecasting and Combining Competing Models of Exchange Rate Determination, June 2006

1748 Olaf Posch and Klaus Waelde, Natural Volatility, Welfare and Taxation, June 2006

1749 Christian Holzner, Volker Meier and Martin Werding, Workfare, Monitoring, and Efficiency Wages, June 2006

1750 Steven Brakman, Harry Garretsen and Charles van Marrewijk, Agglomeration and Aid, June 2006

1751 Robert Fenge and Jakob von Weizsäcker, Mixing Bismarck and Child Pension Systems: An Optimum Taxation Approach, June 2006

1752 Helge Berger and Michael Neugart, Labor Courts, Nomination Bias, and Unemployment in Germany, June 2006

1753 Chris van Klaveren, Bernard van Praag and Henriette Maassen van den Brink, A Collective Household Model of Time Allocation - a Comparison of Native Dutch and Immigrant Households in the Netherlands, June 2006

1754 Marko Koethenbuerger, Ex-Post Redistribution in a Federation: Implications for Corrective Policy, July 2006

1755 Axel Dreher, Jan-Egbert Sturm and Heinrich Ursprung, The Impact of Globalization on the Composition of Government Expenditures: Evidence from Panel Data, July 2006

1756 Richard Schmidtke, Private Provision of a Complementary Public Good, July 2006

1757 J. Atsu Amegashie, Intentions and Social Interactions, July 2006 
1758 Alessandro Balestrino, Tax Avoidance, Endogenous Social Norms, and the Comparison Income Effect, July 2006

1759 Øystein Thøgersen, Intergenerational Risk Sharing by Means of Pay-as-you-go Programs - an Investigation of Alternative Mechanisms, July 2006

1760 Pascalis Raimondos-Møller and Alan D. Woodland, Steepest Ascent Tariff Reforms, July 2006

1761 Ronald MacDonald and Cezary Wojcik, Catching-up, Inflation Differentials and Credit Booms in a Heterogeneous Monetary Union: Some Implications for EMU and new EU Member States, July 2006

1762 Robert Dur, Status-Seeking in Criminal Subcultures and the Double Dividend of ZeroTolerance, July 2006

1763 Christa Hainz, Business Groups in Emerging Markets - Financial Control and Sequential Investment, July 2006

1764 Didier Laussel and Raymond Riezman, Fixed Transport Costs and International Trade, July 2006

1765 Rafael Lalive, How do Extended Benefits Affect Unemployment Duration? A Regression Discontinuity Approach, July 2006

1766 Eric Hillebrand, Gunther Schnabl and Yasemin Ulu, Japanese Foreign Exchange Intervention and the Yen/Dollar Exchange Rate: A Simultaneous Equations Approach Using Realized Volatility, July 2006

1767 Carsten Hefeker, EMU Enlargement, Policy Uncertainty and Economic Reforms, July 2006

1768 Giovanni Facchini and Anna Maria Mayda, Individual Attitudes towards Immigrants: Welfare-State Determinants across Countries, July 2006

1769 Maarten Bosker and Harry Garretsen, Geography Rules Too! Economic Development and the Geography of Institutions, July 2006

1770 M. Hashem Pesaran and Allan Timmermann, Testing Dependence among Serially Correlated Multi-category Variables, July 2006

1771 Juergen von Hagen and Haiping Zhang, Financial Liberalization in a Small Open Economy, August 2006 